University of Nebraska - Lincoln

DigitalCommons@University of Nebraska - Lincoln

Sociology Department, Faculty Publications

Sociology, Department of

8-2005

\title{
Effects of Parental Rejection and Relationship Quality on Depression among Older Rural Adults
}

Jim P. Stimpson

Sealy Center on Aging, University of Texas Medical Branch

Kimberly A. Tyler

University of Nebraska-Lincoln, kim@ktresearch.net

Dan R. Hoyt

University of Nebraska-Lincoln, dhoyt2@unl.edu

Follow this and additional works at: https://digitalcommons.unl.edu/sociologyfacpub

Part of the Sociology Commons

Stimpson, Jim P.; Tyler, Kimberly A.; and Hoyt, Dan R., "Effects of Parental Rejection and Relationship Quality on Depression among Older Rural Adults" (2005). Sociology Department, Faculty Publications. 63. https://digitalcommons.unl.edu/sociologyfacpub/63

This Article is brought to you for free and open access by the Sociology, Department of at DigitalCommons@University of Nebraska - Lincoln. It has been accepted for inclusion in Sociology Department, Faculty Publications by an authorized administrator of DigitalCommons@University of Nebraska - Lincoln. 


\title{
EFFECTS OF PARENTAL REJECTION AND RELATIONSHIP QUALITY ON DEPRESSION AMONG OLDER RURAL ADULTS
}

\author{
JIM P. STIMPSON \\ Sealy Center on Aging, University of Texas Medical Branch \\ KIMBERLY A. TYLER
}

DAN R. HOYT

University of Nebraska-Lincoln

\begin{abstract}
Research suggests that families have development histories which influence their responses to situations across the life course. The present study examined the effects of family relationship histories on intergenerational affection and conflict between adult children and their parents and how this affects parents' depressive symptoms. Path analysis based on matched reports of adult children and their parents revealed that parental behavior early in life affects contemporary relationships between family members, which ultimately impacts parents' depressive symptoms. Parental rejection is negatively associated with intergenerational affection, which in turn is negatively associated with depressive symptoms.
\end{abstract}

Increases in life expectancy and decreases in fertility over the past century have produced significant changes in family configurations. Families have become vertical with fewer members in each generation but more generations alive at any given time (Himes, 2001). Americans are not only living longer lives, but also healthier lives. These patterns mean that older adults will form long-term relationships with the rest of the family. With life expectancy now exceeding 75 years, parents and children may develop relationships that last over 50 years

(C) 2005, Baywood Publishing Co., Inc. 
(Farkas \& Hogan, 1995). These extended relationships significantly impact family dynamics (Bengtson, 1993); yet, we still know little about this increasingly common intergenerational relationship (Giarrusso, Feng, Silverstein, \& Bengtson, 2001).

These demographic changes critically impact rural families. As young people migrate to urban areas in search of economic opportunities (Lasley, 1994; Lichter, 1993), rural populations are becoming older with fewer young people to support the elderly. Rural families face significant obstacles as the economic crises of the past decade produced fewer employment opportunities and increasing poverty rates (Bloomquist, Gringeri, Tomaskovic-Devey, \& Truelove, 1993; Duncan, 1992; Lichter, Johnston, \& McLaughlin, 1994). This continued economic stagnation has led some scholars to identify an emergence of rural ghettos (Davidson, 1996), which leaves little infrastructure to support family issues (Lasley, 1994). Consequently, the diminishing economic and social conditions in rural areas put families at increased risk for psychological distress (Conger \& Elder, 1994; Hoyt, Conger, Valde, \& Weihs, 1997; Hoyt, O’Donnell, \& Mack, 1995; Lorenz, Conger, \& Montague, 1994; Pearlin, Lieberman, Menaghan, \& Mullan, 1981).

Research suggests that families have development histories that influence their responses to situations across the life course (Parrott \& Bengtson, 1999; Whitbeck, Hoyt, \& Huck, 1994; Whitbeck, Hoyt, \& Tyler, 2001; Whitbeck, Lorenz, Simons, \& Huck, 1994; Whitbeck, Simons, \& Conger, 1991). What the literature has not clearly shown is how this process operates within a rural context where families lack institutional support for adapting to shifting economic forces. The result is an overall decrease in well-being that both affects and is affected by family relations (Conger \& Elder, 1994). The support children provide to elderly parents in rural families is all the more important given the diminishing resources at their disposal. The present study uses a rural sample to examine the effects of family relationship histories on contemporary intergenerational affection and conflict between adult children and their parents and how this affects parents' depressive symptoms.

\section{LITERATURE REVIEW}

Family history is important for contemporary family relationships (Rossi \& Rossi, 1990; Schaie \& Wills, 1995; Whitbeck et al., 2001). Most research on adult child-parent relationships tends to ignore the theoretical underpinnings of family history. For example, Bengtson and Roberts (1991) put forth a theory on intergenerational solidarity that includes several dimensions of solidarity, such as affection and consensual, but did not address how solidarity changes over time and is affected by family history. Although solidarity is important and research has attempted to verify this theory (Atkinson, Kivett, \& Campbell, 1986; Roberts \& Bengtson, 1990), these tests have not provided deeper insight into family 
history, which may be the more important dynamic impacting family relationships (Atkinson, 1989) because early parent-child relationships affect current solidarity (Rossi \& Rossi, 1990). Recent research has emerged that documents the effects of family history on parental divorce (Webster \& Herzog, 1995), exchanges of help and support (Parrott \& Bengtson, 1999), conflict (Clarke, Preston, Raksin, \& Bengtson, 1999), depression (Whitbeck et al., 2001), and reciprocity (Silverstein, Conroy, Wang, Giarrusso, \& Bengtson, 2002).

Early parent-child interaction patterns frame a lifelong series of events by influencing mutual interpretations of these events and expectations that are constantly reinforced over the life course (Rossi \& Rossi, 1990). As people live longer, we are faced with a unique situation where bonds between parent and child persist into the child's middle adulthood and sometimes even into old age. Interaction styles develop from early life experiences, and these styles are continually reinforced as individuals select themselves into social networks that are consistent with past interaction styles (Caspi, Bem, \& Elder, 1989; Whitbeck et al., 1991). That family interaction patterns learned early in life are repeated later in life is suggestive of a social learning approach to intergenerational relationships (Rossi \& Rossi, 1990). Parents instill distinct attitudes and behaviors early in a child's life, and these relationship styles persist into adulthood. In turn, children will likely model these roles later in life when they become parents (Caspi et al., 1989; Caspi \& Elder, 1988).

Past studies, particularly those based on solidarity, may have ignored critical components of the family experience by not asking about negative feelings (Luescher \& Pillemer, 1998). An adult child could potentially have a relationship with their aging parent that is both demanding and fulfilling, close and stressful (Willson, Shuey, \& Elder, 2003). This underresearched aspect of family relationships underscores the recent debate in the scholarly literature about ambivalence in intergenerational relations. To understand the quality of parent-child relations, several scholars agreed that it is important to incorporate both positive and negative elements because family members rarely have one-sided feelings, and thus, our models should reflect conflicting thoughts and feelings (Bengtson, Giarrusso, Mabry, \& Silverstein, 2002; Connidis \& McMullin, 2002; Curran, 2002; Luscher, 2002).

Intergenerational affection and conflict, which are linked to family history, impact various outcomes, such as social support and depression. Adults who recalled early parental rejection tended to express less concern for staying in touch with parents and monitoring parents' well-being. Perceived parental rejection also held a strong, negative correlation with contemporary affection and positively associated with relationship strain (Clarke et al., 1999; Whitbeck et al., 1994). The quality of intergenerational relations can affect assistance to parents as the shift in dependency from child to parent occurs later in life (Dunham, 1995; Mutran \& Reitzes, 1984; Silverstein et al., 2002; Whitbeck et al., 1991). Another study also found that contemporary family relationships mediated 
the effect of parental rejection in provision of instrumental and emotional support. Having negative experiences early in life decreased the willingness of children to provide support to their parents. Moreover, providing assistance to parents tends to erode the relationship over time (Whitbeck et al., 1994).

Whitbeck et al. (2001) reported not only that family history impacted contemporary relations, but that relationship quality was negatively associated with depressive symptoms. Although, the effect of family history did not carry a direct impact upon depression, its impact was meditated through contemporary relationship quality. One important implication the authors draw from these findings is that early patterns of interaction seem to be continually reinforced over the life course leading to lessened support, contact, and affection when those interaction patterns are negative. The lack of affectional solidarity, brought about by poor relationships, is especially important for men (Elder, Rudkin, \& Conger, 1995). Some scholars have suggested that marital status plays a key role in determining mental health outcomes because unmarried men are particularly vulnerable to depression and loneliness (Zhang \& Hayward, 2001).

\section{Statement of the Problem}

Past research has included a broad range of solidarity measures (Logan \& Spitze, 1996; Rossi \& Rossi, 1990) and provided support that family history impacts contemporary solidarity (Whitbeck et al., 1994). Although Whitbeck and colleagues (2001) have looked at how this process operates for rural families, and our study closely follows this example, they assumed affection and conflict operated as opposite ends of a continuum. We do not make this assumption in our study, and instead define them as separate dimensions of solidarity and therefore correlate these items in the analysis, unlike past research, to reflect their underlying association.

Some research has proposed a link between conflict and depressive symptoms (Whitbeck et al., 2001); other theoretical work indicates that this link is unlikely to exist since elderly parents tend to interpret relationships with their children positively (Winkeler, Filipp, \& Boll, 2000), especially if they have a stake in the relationship (Giarrusso, Stallings, \& Bengtson, 1995). Because rural respondents may be more likely to have a stake in the relationship, given the depressed economic conditions and the geographic distance of their family, we propose that conflict is unlikely to be associated with depressive symptoms. Another significant limitation of past research has been the exclusion of critical demographic variables, such as income, marital status, and prior depression; this model will account for the elderly parent's gender, prior depression, age, marital status, income, and health limitations when predicting relationship quality and depressive symptoms.

This study examines the effects of parental rejection on intergenerational affection and conflict between adult children and their elderly parents and how this 
affects parents' depressive symptoms. Rural families have fewer resources and infrastructure at their disposal, which would make family relationships more important. We expect that perceptions by adult children that parents rejected them will be related to affection, which will serve as a mediating agent for depressive symptoms. Like previous studies, we conceptualize our model within a life course perspective. This analysis is unique in its treatment of intergenerational relationships since we assume that conflict will only be associated with control variables. Moreover, we incorporate a wide range of variables commonly associated with depression, such as income and prior depression, which have been excluded from past research. Figure 1 provides a diagram depicting our conceptual model. Our sample is unique since it is one of the few available that specifically targets our population of interest - rural families. Finally, our analytic strategy makes use of new software that handles missing data without deleting cases and has extremely robust algorithms for estimating model parameters.

\section{METHOD}

\section{Sample}

The data were drawn from a 1992 study of the social support networks of the rural small town elderly. Four communities were sampled from a frame of small

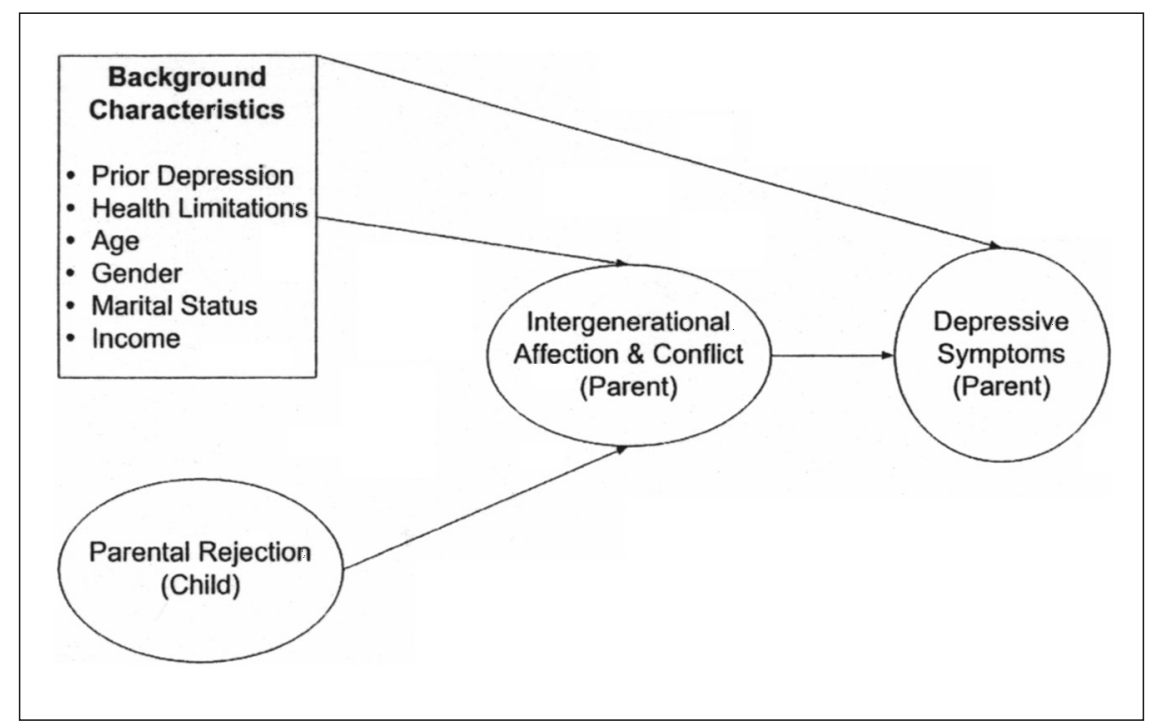

Figure 1. The conceptual model. 
towns (2,500 or less) located in rural counties (no place larger than 5,000 and non-adjacent to an urbanized county) in the state of Iowa. Characteristic of rural towns in the region, each of the sample communities had at least $25 \%$ of the population who were over the age of 60 . Also consistent with the rural demographic trends in this region, each town was located in a county that had experienced natural population decline in the past 10 years. Within each community, a random selection of households was screened by telephone for residents aged 60 or older. In households with two or more elderly respondents, the person to be interviewed was randomly selected. The interviews were then scheduled and conducted in-person. The response rate for the adults was $84 \%$. A total of 115 personal interviews were conducted with persons age 60 or older. Fifteen of the respondents had no living children, 10 had one, and 90 had two or more. Permission was obtained from 92 of the respondents with children to contact one or two children to get information on their relationship. The children to be contacted were selected randomly. Telephone interviews were completed with $132(75.9 \%)$ of the eligible adult children. Some of the children from the 92 respondents who gave permission did not respond, and in other cases, more than one child per parent responded.

A quarter of the eligible children from the 92 parents did not respond. To create a matched response between an elderly parent and adult child, our sample used parent reports where an adult child responded to the survey. The 132 adult children were randomly selected; however, there were cases in which more than one child from a parent responded to the survey. In cases where more than one child from a parent responded, we selected the most proximate child in geographic distance. Using the most proximate child allows us to control for the effects of structural solidarity (Bengston \& Roberts, 1991). The final sample consisted of 72 dyads with both an adult child and a parent report.

The average age of the parents was 71 and ranged from 60 to 91 years, while the average age of the child was 46 and ranged from 29 to 65 years. About $56 \%$ of the adult children and parents were female and $44 \%$ were male. Almost three-fourths of the adult children made over $\$ 25,000$, and $86 \%$ were married. The gender composition of the dyads was almost evenly split: father/son (21\%), father/daughter (24\%), mother/son (24\%), and mother/daughter (32\%).

\section{Measures}

Depressive symptoms were measured using a 12-item variation of the Center for Epidemiological Studies Depression Scale (CES-D) developed by Ross and Huber (1985). This short version has a simpler factor structure and drops a number of the items that do not load equally well for men and women (e.g., many of the items that tap somatic components). Refer to the appendix for a list of the items used in this index. The responses were coded for the number of days in the past week that each symptom was present. The lowest and most frequent report was 
zero days, and the highest report was seven days. We added the responses together and then divided by the number of items giving this index a range from 0 to 5.97 and a mean of .69. The alpha reliability for this scale was .84. About a third of the respondents reported they were not at all depressed, leaving two-thirds of the sample reporting some symptoms of depression.

Reports of the early life behaviors of their parents were obtained by asking the adult children to report on their relationships with their parents when they were adolescents, about 13 years of age. This referent age provides two advantages (Whitbeck et al., 1994). First, early adolescence is advanced enough in age for the child to have clear recall. Second, it is at a point in the parent-child relationship where we are likely to obtain greater variation in conflict and affection. For example, adolescence is associated with less affective closeness to parents than either earlier or later points in the life course (Rossi \& Rossi, 1990). Refer to the Appendix for a list of the items used in constructing each index.

The measure of early relationship history used in this analysis is parental rejection. Five global recall questions were administered to the adult children. Two questions assessed how much the adult child felt the parent cared for and trusted them. Both of these items were coded so that a higher score would represent more rejecting behaviors. Three questions reported how much the parents blamed them for problems, were dissatisfied with them, and found fault with the adult child when not deserved. All items used a 5-point Likert agreedisagree scale. The five items were summed such that higher scores indicate more rejecting behavior. The alpha reliability coefficient for this measure was .78.

Intergenerational affection was measured using two items drawn from Bengtson's indicators of affectional solidarity (Bengston \& Roberts, 1991). The questions assessed the elderly parent's feelings about his/her relationship with the selected child at the present time. One question centered on how close the relationship is with their child. The other measured how well the elderly respondent and child got along together. A high score represents greater positive affect. The alpha coefficient was .79.

Intergenerational conflict consisted of two indicators. The first item asked the elderly parent the degree to which their child is critical of them. The second item assessed how much conflict, tension, or disagreement the parent feels with his/her child. These items were scored the same as the positive affect measures, and a high score indicates greater conflict. These items had an alpha coefficient of .63.

\section{Control Variables}

Parent's gender was dummy coded, with males as the reference category $($ Male $=0$, Female $=1)$. Health limitations were calculated by summing affirmative responses to having health-related limits across five activities of daily living dimensions. Parent's marital status was also dummy coded with not married (e.g., never married, widowed, divorced) as the reference category (Not 
Married $=0$, Married $=1)$. Income was coded as an ordinal variable with nine categories ranging from below $\$ 5,000$ to $\$ 55,000$ or more.

Earlier life depressive episode was measured using one item from the Diagnostic Interview Schedule. This question asked whether the respondent had experienced depression or sadness most days for at least two years. Other questions from this instrument could not reasonably be used because they asked about depression experiences in the past two weeks or past year. In order to better distinguish between prior depression and depressive symptoms, we measured prior depression using a measure of symptoms that lasted over one year.

\section{Analysis Strategy}

Path analysis using maximum likelihood estimation (ML) tested whether the effect of parental rejection is mediated through contemporary relations. Toward this end, three regression models used intergenerational conflict, intergenerational affection, and depressive symptoms as the dependent variables. Each model incorporated control variables.

All models are estimated in Mplus version 2 (Muthén \& Muthén, 2001), which is a statistical package ideally suited for structural equation models that include dichotomous variables. Another strength of this software package is how it handles missing data. Rather than delete cases with missing data, Mplus uses an algorithm called full information maximum-likelihood (FIML) to create a covariance matrix from all observations. Our data had missing data for income ( 2 cases), affection (4 cases), and rejection ( 2 cases). Further analyses using listwise deletion of cases found no significant differences in results, so the results reported here include the full sample $(n=72)$.

\section{RESULTS}

Table 1 provides means, standard deviations, and the bivariate correlations for all variables used in the analysis. Depressive symptoms was significantly associated with rejection $(r=.257, p<.05)$, prior depression $(r=.339, p<.01)$, health limitations $(r=.534, p<.01)$, and affection $(r=-.337, p<.01)$; noticeably missing from these results is a significant correlation between depressive symptoms and conflict. Affection and conflict are inversely related to each other $(r=-.519, p<.01)$. In addition, affection is associated with rejection $(r=-.356$, $p<.01)$ and conflict is negatively associated with age $(r=-.279, p<.05)$.

Table 2 provides a summary of the results for the path analysis. The first column presents the results for intergenerational affection as the dependent variable. Early parental rejection had a significant negative effect on contemporary intergenerational affection indicating that children's perceptions of rejection and parent's report of affection are associated. Older respondents reported higher 
RURAL FAMILY RELATIONSHIPS AND DEPRESSION / 203

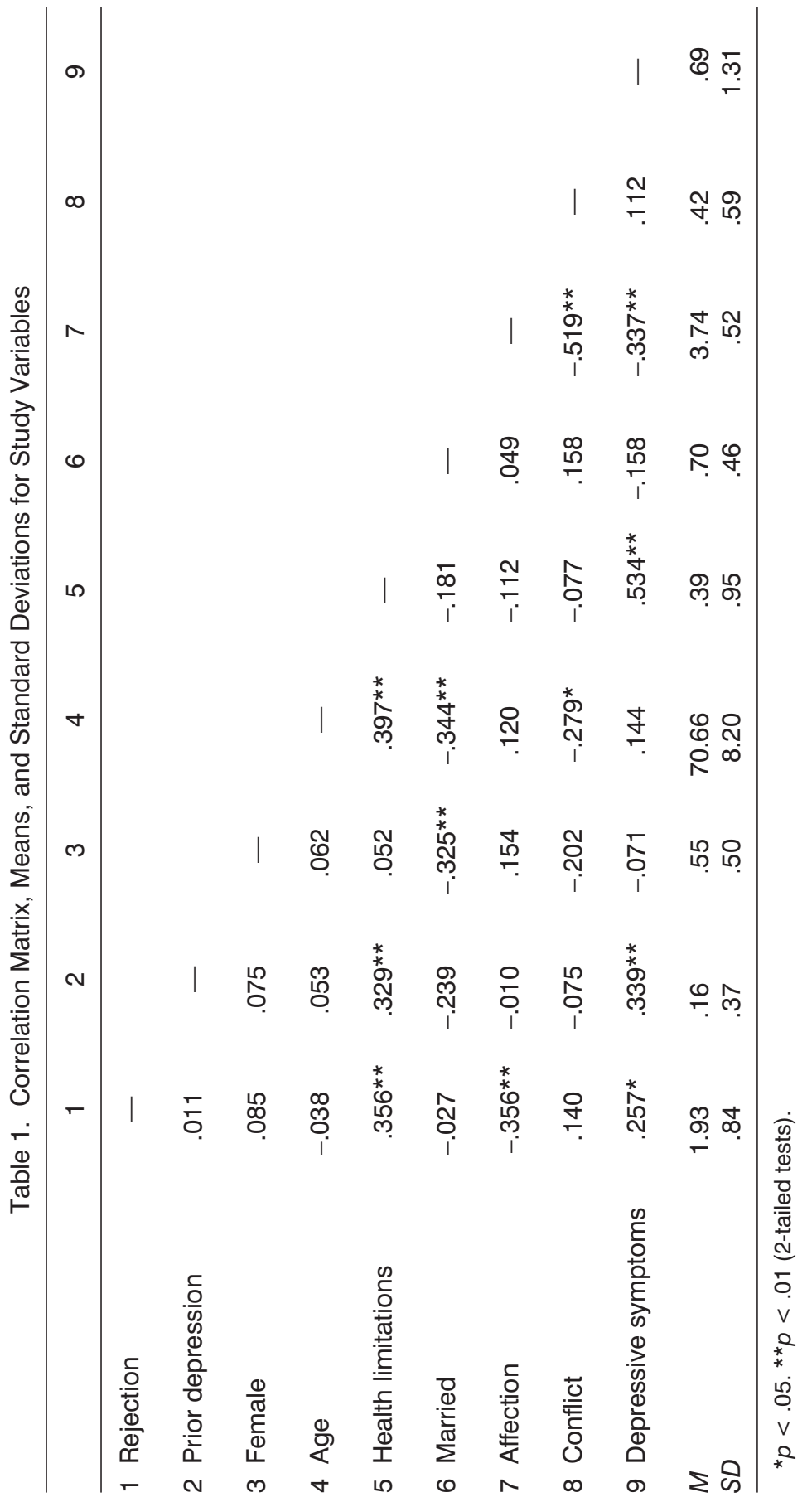


Table 2. Maximum Likelihood Estimates of Intergenerational Affection, Intergenerational Conflict, and Depressive Symptoms on

Selected Independent Variables

\begin{tabular}{|c|c|c|c|c|}
\hline & Affection & Conflict & $\begin{array}{c}\text { Depression } \\
\text { Model } 1\end{array}$ & $\begin{array}{c}\text { Depression } \\
\text { Model } 2\end{array}$ \\
\hline Rejection & $\begin{array}{c}-.156 \\
(-2.009)\end{array}$ & $\begin{array}{l}.034 \\
(.324)\end{array}$ & $\begin{array}{l}-.025 \\
(-.136)\end{array}$ & $\begin{array}{l}-.129 \\
(-.716)\end{array}$ \\
\hline Prior depression & $\begin{array}{c}.129 \\
(.750)\end{array}$ & $\begin{array}{l}.111 \\
(.497)\end{array}$ & $\begin{array}{c}.616 \\
(1.504)\end{array}$ & $\begin{array}{c}.655 \\
(1.743)\end{array}$ \\
\hline Female & $\begin{array}{c}.263 \\
(2.190)\end{array}$ & $\begin{array}{c}-.165 \\
(-1.074)\end{array}$ & $\begin{array}{c}-.419 \\
(-1.475)\end{array}$ & $\begin{array}{l}-.245 \\
(.864)\end{array}$ \\
\hline Age & $\begin{array}{c}.019 \\
(1.980)\end{array}$ & $\begin{array}{c}-.020 \\
(-1.651)\end{array}$ & $\begin{array}{c}-.023 \\
(-1.041)\end{array}$ & $\begin{array}{l}-.009 \\
(-.433)\end{array}$ \\
\hline Income & $\begin{array}{c}.055 \\
(1.535)\end{array}$ & $\begin{array}{c}-.013 \\
(-.267)\end{array}$ & $\begin{array}{l}-.054 \\
(-.629)\end{array}$ & $\begin{array}{l}-.024 \\
(-.281)\end{array}$ \\
\hline Health limitations & $\begin{array}{l}-.066 \\
(-.853)\end{array}$ & $\begin{array}{l}-.017 \\
(-.166)\end{array}$ & $\begin{array}{c}.677 \\
(3.689)\end{array}$ & $\begin{array}{c}.651 \\
(3.650)\end{array}$ \\
\hline Married & $\begin{array}{c}.178 \\
(1.282)\end{array}$ & $\begin{array}{l}-.022 \\
(-.128)\end{array}$ & $\begin{array}{c}-.298 \\
(-.922)\end{array}$ & $\begin{array}{l}-.199 \\
(-.0631)\end{array}$ \\
\hline Affection & & & & $\begin{array}{c}-.546 \\
(-1.676)\end{array}$ \\
\hline Conflict & & & & $\begin{array}{l}.195 \\
(.830)\end{array}$ \\
\hline Intercept & 2.198 & 1.908 & 1.329 & 3.655 \\
\hline$R^{2}$ & .220 & .087 & .305 & .362 \\
\hline
\end{tabular}

Note: Unstandardized regression coefficients with $t$-ratios in parentheses are shown.

intergenerational affection, and female respondents reported higher affection than male respondents. Overall, $22 \%$ of the variance around affection was explained.

The second column presents intergenerational conflict as the dependent variable and accounted for $9 \%$ of the variance. Only the age of the parent significantly predicted conflict where older parents reported the least intergenerational conflict. That age was associated with more affection and less conflict is consistent 
with past research indicating the elderly are less likely to report conflict and more likely to report positive relations with their children (Giarrusso et al., 1995; Winkeler et al., 2000).

In the next column, we show the results from regressing the control variables and parental rejection onto depression in order to demonstrate the direct effects of rejection on depressive symptoms. There is no evidence that rejection directly influences depression. As expected, health limitations was positively associated with depression. This equation accounted for about $31 \%$ of the variance around depression. Both measures of intergenerational ties were then regressed on contemporary depressive symptoms. The final column accounted for about $36 \%$ of the variance in depressive symptoms. Consistent with the previous column, in which affection and conflict were excluded, health limitations was significantly associated with depression. In addition, those with a history of depression reported more depressive symptoms. To improve model fit and control for the relatively high zero order correlation between affection and conflict, we correlated these variables in the model predicting depressive symptoms. Higher levels of affection with the adult child, as reported by the parent, were significantly associated with lower levels of depressive symptoms.

\section{DISCUSSION}

This study examined the effects of parental rejection on intergenerational affection and conflict between adult children and their elderly parents and how this affects parents' depressive symptoms. Overall, we found support for our proposed model. Most notably, we found a negative association between past parental rejection and current filial affection. Affection then mediated the depressive effect of parental rejection. In addition, intergenerational affection was greater for females, and intergenerational conflict lessened with age. This evidence suggests that family history affected contemporary relationships between family members, which ultimately impacted parents' depressive symptoms.

Unlike affection, intergenerational conflict was not significantly associated with depressive symptoms. This finding is consistent with previous reports that elderly parents may be inclined to report positive associations and underreport negative associations (Giarrusso et al., 1995). Furthermore, children from rural families tend to stay proximal to their parents (Conger \& Elder, 1994), which in turn leads to more contact and better relations (Elder et al., 1995). We might also speculate from this finding that affection and conflict are not simply opposite ends of a continuum of solidarity but are instead separate dimensions with their own unique pathways (Connidis \& McMullin, 2002).

Rural families, particularly elderly parents, are at increased risk for psychological distress (Conger \& Elder, 1994). With diminishing social and economic resources at one's disposal, fostering warm, supportive relationships with children early in life may be important later in life as parents need to draw on family 
resources. Past research on the economic deterioration of rural communities may point to one possible avenue of support for rural families. By improving rural economic conditions, families might experience less stress which could improve intergenerational relationships and might also pave the way for more young people to remain in the rural community. Improved family relations and a younger demographic profile might create enough social support to buffer parental distress later in life.

This study has some limitations. The data used for this study were a small, rural, cross-sectional sample. However, these data represent one of the few samples that focus on rural elderly, and we feel confident in our findings given the relatively low statistical power from using a small sample. In fact, the negative economic changes that have hit rural regions since these data were collected lead us to suspect our findings may be even more robust under current socioeconomic conditions. Although well suited to study rural family issues, larger, more representative samples using prospective designs will yield more definitive results. This recommendation leads to another limitation to consider. We have relied on retrospective accounts of family events rather than prospective accounts. For example, respondents may have inaccurately recalled their early family relationships. Although other scholars argue this is a valid measure (Schaie \& Wills, 1995; Webster \& Herzog, 1995; Whitbeck et al., 1991, 2001), prospective studies using a life diary may yield more accurate results. Finally, there may be issues with how these variables were measured. Given that there are no standards and that we utilized existing benchmarks, we believe this issue has been lessened.

This study provided evidence that parenting has long term consequences well into old age. Negative parent-child relationships early in life may translate into negative relationships later in life, which will become more important as parents live longer lives and consequently maintain longer relationships with their children.

\section{APPENDIX \\ Items Used in Constructing Indices}

\section{Parental Rejection}

Coded strongly disagree to strongly agree

1. My parent really trusted me.

2. My parent found fault with me even when I didn't deserve it.

3. My parent really cared for me.

4. My parent was dissatisfied with the things I did.

5. My parent blamed me for [his or her] problems. 


\section{Intergenerational Conflict}

Coded: $0=$ Not at all, $1=$ A little, $2=$ Some, $3=$ Pretty much, $4=$ Quite a bit, $5=$ A great deal

1. Taking everything into consideration, how much conflict, tension, or disagreement do you feel there is between you and [name] at this point in your life?

2. How much do you feel [name] is critical of you or what you do?

\section{Intergenerational Affection}

Coded: $0=$ Not at all close/well, $1=$ Not too close/well, $2=$ Somewhat close/well, $3=$ Pretty close/well, $4=$ Very close/well, $5=$ Extremely close/well

1. Taking everything into consideration, how close do you feel the relationship is between you and [name] at this point in your life?

2. Overall, how well do you and [name] get along together at this point in your life?

\section{Health Limitations}

Coded: $0=$ No, $1=$ Yes

Do you have a physical condition that limits your ability to:

1. Care for personal needs, such as dressing, eating, or going to the bathroom?

2. Move about inside the house?

3. Do day-to-day household tasks?

4. Climb a flight of stairs?

5. Walk six blocks?

\section{Depressive Symptoms (Distress)}

On how many days in the past week did you:

1. Feel bothered by things that usually don't bother you?

2. Not feel like eating; your appetite was poor?

3. Feel that you could not shake off the blues even with help from your family or friends?

4. Have trouble keeping your mind on what you were doing?

5. Feel depressed?

6. Feel that everything you did was an effort?

7. Feel fearful?

8. Sleep restlessly?

9. Talk less than usual? 
10. Feel lonely?

11. Feel sad?

12. Feel you could not get going?

\section{REFERENCES}

Atkinson, M. P. (1989). Conceptualizations of the parent-child relationship: Solidarity, attachment, crescive bonds, and identity salience. In J. A. Mancini (Ed.), Aging Parents and Adult Children (pp. 81-97). Lexington, MA: Lexington Books.

Atkinson, M. P., Kivett, V. R., \& Campbell, R. T. (1986). Intergenerational solidarity: An examination of a theoretical model. Journal of Gerontology, 41, 408-416.

Bengtson, V. L. (1993). Is the "contract across generations"" changing? Effects of population aging on obligations and expectations across age groups. In V. L. Bengtson \& W. Achenbaum (Eds.), The changing contract across generations (pp. 3-23). New York: Aldine de Gruyter.

Bengtson, V. L., Giarrusso, R., Mabry, J. B., \& Silverstein, M. (2002). Solidarity, conflict, and ambivalence: Complementary or competing perspectives on intergenerational relationships? Journal of Marriage and Family, 64, 568-576.

Bengston, V. L., \& Roberts R. E. (1991). Intergenerational solidarity in aging families: An example of formal theory construction. Journal of Marriage and the Family, 53, 856-870.

Bloomquist, L., Gringeri, C., Tomaskovic-Devey, D., \& Truelove, C. (1993). Work structures and rural poverty. In Rural Sociology Society Task Force on Persistent Rural Poverty (Ed.), Persistent rural poverty in rural america (pp. 68-105). Boulder, CO: Westview.

Caspi, A., Bem D. J., \& Elder G. H. (1989). Continuities and consequences of interactional styles across the life course. Journal of Personality, 57, 375-406.

Caspi, A., \& Elder G. H. (1988). Emergent family patterns: The intergenerational construction of problem behavior and relationships. In R. H. Hinde \& J. S. Hinde (Eds.), Relationships within families (pp. 218-240). Oxford: Clarendon Press.

Clarke, E. J., Preston M., Raksin J., \& Bengtson V. L. (1999). Types of conflicts and tensions between older parents and adult children. The Gerontologist, 39, 261-270.

Conger, R. D., \& Elder, G. H. (1994). Family stress and adaptation: Reviewing the evidence. In R. D. Conger \& G. H. Elder (Eds.), Families in troubled times: Adapting to change in rural america (pp. 255-268). New York: Aldine De Gruyter.

Connidis, I. A., \& McMullin, J. A. (2002). Sociological ambivalence and family ties: A critical perspective. Journal of Marriage and Family, 64, 558-567.

Curran, S. R. (2002). Agency, accountability, and embedded relations: "What's love got to do with it?" Journal of Marriage and Family, 64, 577-584.

Davidson, O. G. (1996). Broken heartland: The rise of America's rural ghetto. Iowa City, IA: University of Iowa Press.

Duncan, C. M. (1992). Rural poverty in america. New York: Auburn House.

Dunham, C. C. (1995). A link between generations: Intergenerational relations and depression in aging parents. Journal of Family Issues, 16, 450-465.

Elder, G. H., Rudkin, L., \& Conger, R. D. (1995). Intergenerational continuity and change in rural America. In V. L. Bengtson, K. W. Schaie, \& L. M. Burton (Eds.), Adult intergenerational relations: Effects of societal change (pp. 30-60). New York: Springer. 
Farkas, J. I., \& Hogan, D. P. (1995). The demography of changing intergenerational relationships. In V. L. Bengtson, K. W. Schaie, \& L. M. Burton (Eds.), Adult intergenerational relations: Effects of societal change (pp. 1-18). New York: Springer.

Giarrusso, R., Feng, D., Silverstein, M., \& Bengston, V. L. (2001). Grandparent-adult grandchild affection and consensus. Journal of Family Issues, 22, 456-477.

Giarrusso, R., Stallings, M., \& Bengtson, V. L. (1995). The intergenerational stake hypothesis revisited: Parent-child differences in perceptions of relationships 20 years later. In V. L. Bengtson, K. W. Schaie, \& L. M. Burton (Eds.), Adult intergenerational relations: Effects of societal change (pp. 227-263). New York: Springer.

Himes, C. L. (2001). Elderly Americans. Population Bulletin, 56, 1-40.

Hoyt, D. R., Conger, R. D, Valde, J. G., \& Weihs, K. (1997). Psychological distress and help seeking in rural America. American Journal of Community Psychology, 25, 449-470.

Hoyt, D. R., O’Donnell, D., \& Mack, K. Y. (1995). Psychological distress and size of place: The epidemiology of rural economic stress. Rural Sociology, 60, 707-720.

Lasley, P. (1994). Rural economic and social trends. In R. D. Conger \& G. H. Elder (Eds.), Families in troubled times: Adapting to change in rural America (pp. 57-78). New York: Aldine De Gruyter.

Lichter, D. (1993). Migration, population redistribution, and the new spatial inequality. In D. Brown, D. Field, \& J. Zuiches (Eds.), The demography of rural life (pp. 19-46). University Park, PA: Northeast Regional Center for Rural Development.

Lichter, D., Johnston, G. M., \& McLaughlin, D. K. (1994). Changing linkages between work and poverty in rural America. Rural Sociology, 59, 395-415.

Logan, J. R., \& Spitze, G. D. (1996). Family ties: Enduring relations between parents and their grown children. Philadelphia: Temple University Press.

Lorenz, F. O., Conger, R. D., \& Montague, R. (1994). Doing worse and feeling worse: Psychological consequences of economic hardship. In R. D. Conger \& G. H. Elder (Eds.), Families in troubled times: Adapting to change in rural America (pp. 167-186). New York: Aldine De Gruyter.

Luescher, K. (2002). Intergenerational ambivalence: Further steps in theory and research. Journal of Marriage and Family, 64, 585-593.

Luescher, K., \& Pillemer, K. (1998). Intergenerational ambivalence: A new approach to the study of parent-child relations in later life. Journal of Marriage and the Family, 60, 413-425.

Muthén, L. K., \& Muthén B. O. (2001). Mplus user's guide (2nd ed.). Los Angeles: Muthén \& Muthén.

Mutran, E., \& Reitzes, D. C. (1984). Intergenerational support activities and well-being among the elderly: A convergence of exchange and symbolic interaction perspectives. American Sociological Review, 49, 117-130.

Parrott, T. M., \& Bengtson, V. L. (1999). The effects of earlier intergenerational affection, normative expectations, and family conflict on contemporary exchanges of help and support. Research on Aging, 21, 73-105.

Pearlin, L., Lieberman, M., Menaghan, E., \& Mullan, J. (1981). The stress process. Journal of Health and Social Behavior, 22, 337-356.

Roberts, R. E., \& Bengtson, V. L. (1990). Is integenerational solidarity a unidimensional construct? A second test of a formal model. Journal of Gerontology: Social Sciences, 45, S512-S520. 
Ross, C. E., \& Huber, J. (1985). Hardship and depression. Journal of Health and Social Behavior, 26, 312-327.

Rossi, A. S., \& Rossi, P. H. (1990). Of human bonding: parent-child relations across the life course. New York: Aldine de Gruyter.

Schaie, K. W., \& Wills, S. L. (1995). Perceived family environments across generations. In V. L. Bengtson, K. W. Schaie, \& L. M. Burton (Eds.), Adult intergenerational relations: Effects of societal change (pp. 174-209). New York: Springer.

Silverstein, M., Conroy, S. J., Wang, H., Giarrusso, R., \& Bengtson, V. L. (2002). Reciprocity in parent-child relations over the adult life course. Journal of Gerontology: Social Sciences, 57B, S3-S13.

Webster, P. S., \& Herzog, A. R. (1995). Effects of parental divorce and memories of family problems on relationships between adult children and their parents. Journal of Gerontology: Social Sciences, 50B, S24-S34.

Whitbeck, L. B., Hoyt, D. R., \& Huck, S. M. (1994). Early family relationships, intergenerational solidarity, and support provided to parents by their adult children. Journal of Gerontology, 49, S85-S94.

Whitbeck, L. B., Hoyt, D. R., \& Tyler, K. A. (2001). Family relationship histories, intergenerational relationship quality, and depressive affect among rural elderly people. Journal of Applied Gerontology, 20, 214-229.

Whitbeck, L. B., Lorenz, F. O., Simons, R. L., \& Huck, S. (1994). Family origins of personal and social well-being. In R. D. Conger \& G. H. Elder (Eds.), Families in troubled times: Adapting to change in rural America (pp. 149-165). New York: Aldine De Gruyter.

Whitbeck, L. B., Simons, R. L., \& Conger, R. D. (1991). The effects of early family relationships on contemporary relationships and assistance patterns between adult children and their parents. Journal of Gerontology, 46, S330-S337.

Willson, A. E., Shuey, K. M., \& Elder, G. H. (2003). Ambivalence in the relationship of adult children to aging parents and in-laws. Journal of Marriage and Family, 65, 1055-1072.

Winkeler, M., Filipp, S-H., \& Boll, T. (2000). Positivity in the aged's perceptions of intergenerational relationships: A "stake" or "leniency" effect? International Journal of Behavioral Development, 24, 173-182.

Zhang, Z., \& Hayward, M. D. (2001). Childlessness and the psychological well-being of older persons. Journal of Gerontology: Social Sciences, 56B, S311-S320.

Direct reprint requests to:

Jim P. Stimpson

Sealy Center on Aging

Rte 0460

University of Texas Medical Branch

301 University Blvd.

Galveston, TX 77550-0460

e-mail: jastimps@utmb.edu 